\title{
On the metabolism of benzoic acid by cows on purified protein-free and low-protein feed
}

\author{
M. Kreula, A. Raurama and M. Tegengren \\ Biochemical Research Institute, Kalevankatu 56 B, 00180 Helsinki 18, Finland
}

\begin{abstract}
Two test cows, one adapted to purified, protein-free feed ( 0 -feed, 0 -cow) and the other to a low-protein feed (ULP-feed, ULP-cow) in which $60 \%$ of the nitrogen was derived from urea, were fed single doses of 212 and $193 \mu \mathrm{C}_{1}\left[\right.$ ring $\mathrm{U}^{14} \mathrm{C}$ ] benzoic acid respectively in $0.01 \%$ benzoic acid solution. For five days the milk, faeces and urine were collected quantitatively. Fat, protein and lactose contents of the milk samples were determined and these components were isolated in pure form. 23.5 and $98.8 \%$ respectively of the ${ }^{14} \mathrm{C}$-activity given to the 0 - and ULP-cows was found in the urine, and $2.5 \%$ and $3.0 \%$ in the faeces. Totals of $0.5 \%$ and $0.8 \%$ were recovered in the milk, as found from analyses of whole milk. The sum of the activities in isolated fat, protein and lactose components was $0.2 \%$ for both cows, and only the protein being labelled.
\end{abstract}

\section{Introduction}

In long-term feeding experiments with purified protein-free feed, urea being the sole source of nitrogen $(0$-feed), and with feeds containing small amounts of true protein and large supplements of urea (ULP-feed), considerable differences were found in the milk production of dairy cows. The annual milk yields of the ULP-cows were in general $1000-2000 \mathrm{~kg}$ higher than those of 0 -cows. Reasons for this were sought ever since the start of the experiments, and metabolic differences were also studied (Virtanen 1963, 1966, Virtanen et al. 1972, Mäkinen 1972, Ettala and Kreula 1976).

One of the most characteristic feed differences is the lack of aromatic precursors in 0 -feed. As regards ruminants, very little information is available about the role of the different components of the feed in the formation and metabolism of benzoic acid and its precursors.

In the present study the ability of 0 -cows and ULP-cows to metabolise benzoic acid was investigated by feeding two cows ${ }^{14} \mathrm{C}$-labelled benzoic acid. The excretion of the carbon derived from the benzoic acid in the urine and faeces, as well as its utilisation in the biosynthesis of milk components, was followed. 


\section{Materials and methods}

A single dose containing $212 \mu \mathrm{Ci}\left[\right.$ ring $\left.\mathrm{U}^{-14} \mathrm{C}\right]$ benzoic acid (Radiochemical Centre, Amersham, England) in $700 \mathrm{~g} 0.01 \%$ benzoic acid solution was fed orally to 0-cow Oona. Oona, a $\mathbf{8 . 5}$ year-old Ayrshire, had been on the proteinfree feed ever since it was a heifer. It had last calved in December 1973. During the test period (Nov. 22-27, 1974) the cow consumed an average of $1.4 \mathrm{~kg}$ cellulose strips, $2.8 \mathrm{~kg}$ starch, $1.2 \mathrm{~kg}$ sucrose, $0.1 \mathrm{~kg}$ glucose, $0.1 \mathrm{~kg}$ straw, and $0.26 \mathrm{~kg}$ urea daily. Also the cow was given daily $0.13 \mathrm{~kg}$ vegetable oil (maize/ soyabean 1: 3), $0.54 \mathrm{~kg}$ mineral mixture, vitamin A (100000 I.U.) and vitamin D $\left(\mathrm{D}_{2}+\mathrm{D}_{3}, 20000 \mathrm{I} . \mathrm{U}\right.$.). Once a week the cow received $400 \mathrm{mg}$ DL- $\boldsymbol{a}$-tocopherol. The digestibility of the organic matter was $84 \%$ and the cow drank an average of 451 water per day.

A single dose of $193 \mu \mathrm{Ci}\left[\right.$ ring $\left.\mathrm{U}^{-14} \mathrm{C}\right]$ benzoic acid (Radiochemical Centre, Amersham, England) in $650 \mathrm{~g} 0.01 \%$ benzoic acid solution was fed orally to ULP-cow Euru. Euru was a 17-year old Ayrshire in its second month of lactation. The cow had been on ULP-feed since 1966. During the test period (Feb. 1822 , 1975) Euru consumed daily $9.5 \mathrm{~kg}$ organic matter, of which $1.7 \mathrm{~kg}$ was maize, $6.0 \mathrm{~kg}$ sugar beet pulp, $1.4 \mathrm{~kg}$ hemicellulose powder and $1.5 \mathrm{~kg}$ straw. The cow was also given daily $0.1 \mathrm{~kg}$ vegetable oil, $0.35 \mathrm{~kg}$ urea, $0.37 \mathrm{~kg}$ mineral mixture, vitamin A (100000 I.U.) and vitamin D ( $\mathrm{D}_{2}+\mathrm{D}_{3}, 5000$ I.U.), and further $330 \mathrm{mg}$ DL-a-tocopherol per week. The proportion of urea was about $60 \%$ of the total nitrogen intake; the digestibility of the organic matter was $72 \%$.

The cows were milked in the morning and evening. The milk, faeces and urine were collected quantitatively. The methods of storage and analysis of the samples were those reported earlier (RAURAmaA and KREULA, 1975).

\section{Results}

During the test period Oona produced a total of $26.2 \mathrm{~kg}$ milk, of average compostion: $12.1 \%$ dry matter, $3.1 \%$ fat, $3.5 \%$ protein and $4.7 \%$ lactose.

The corresponding figures for ULP-cow Euru were as follows: $55.3 \mathrm{~kg}$ milk, average composition $12.1 \%$ dry matter, $4.0 \%$ fat, $3.1 \%$ protein and $4.3 \%$ lactose.

The ${ }^{14} \mathrm{C}$-activities of the milk and its components were measured $8.1-118 \mathrm{~h}$ after the administration of the $\left[{ }^{14} \mathrm{C}\right]$ benzoic acid. Of the total activity fed, $0.5 \%$ was transferred to the whole milk with the 0 -cow and $0.8 \%$ with the ULP-cow (Table 1).

Table 1. Distribution of ${ }^{14} \mathrm{C}$ in milk and its components obtained after administration of 212 $\mu \mathrm{Ci}$ [ring $\mathrm{U}^{14} \mathrm{C}$ ] benzoic acid to 0 -cow Oona and of $193 \mu \mathrm{Ci}$ [ring U-14 $\mathrm{C}$ ] benzoic acid to ULPcow Euru.

\begin{tabular}{lcccc}
\hline & \multicolumn{5}{c}{${ }^{14} \mathrm{C}$-activity, } & $\%$ of ${ }^{14} \mathrm{C}$ fed \\
& Whole milk & Fat & Protein & Lactose \\
\hline 0-cow Oona & 0.5 & 0 & 0.2 & 0 \\
ULP-cow Euru & 0.8 & 0 & 0.2 & 0 \\
\hline
\end{tabular}


Table 2. Excretion of ${ }^{14} \mathrm{C}$ in the faeces and urine of 0 -cow Oona after administration of 212 $\mu \mathrm{Ci}$ (ring $\mathrm{U}^{14} \mathrm{C}$ ) benzoic acid.

\begin{tabular}{rrrrrr}
\hline $\begin{array}{c}\text { Hours } \\
\text { after } \\
\text { feeding }\end{array}$ & kg & $\begin{array}{c}\text { Faeces } \\
\text { \% } \text { of }{ }^{14} \mathrm{C} \text { fed }\end{array}$ & \multicolumn{1}{c}{$\begin{array}{c}\text { Urine } \\
\mathrm{kg}\end{array}$} & $\begin{array}{c}{ }^{14} \mathrm{C}-\text {-activity, } \\
\text { of }{ }^{14} \mathrm{C} \text { fed }\end{array}$ \\
\hline 9.1 & 2.6 & 0.0 & 1.6 & 7.9 \\
22.8 & 5.5 & 1.2 & 12.4 & 13.6 \\
33.1 & 3.5 & 0.0 & 11.4 & 1.1 \\
46.7 & 3.7 & 0.3 & 8.5 & 0.4 \\
57.0 & 3.3 & 0.2 & 4.7 & 0.1 \\
70.5 & 3.3 & 0.2 & 4.8 & 0.1 \\
81.3 & 3.9 & 0.2 & 6.6 & 0.1 \\
94.5 & 4.4 & 0.2 & 10.5 & 0.1 \\
1050 & 3.1 & 0.1 & 7.1 & 0.1 \\
118.8 & 4.9 & 0.1 & 14.8 & 0.0 \\
\hline Total & & 2.5 & & 23.5 \\
\hline
\end{tabular}

Table 3. Excretion of ${ }^{14} \mathrm{C}$ in the faeces and urine of ULP-cow Euru after administration of $193 \mu \mathrm{Ci}$ [ring $\mathrm{U}-{ }^{14} \mathrm{C}$ ] benzoic acid.

\begin{tabular}{rrrrrr}
\hline $\begin{array}{c}\text { Hours } \\
\text { after } \\
\text { feeding }\end{array}$ & $\mathrm{kg}$ & $\begin{array}{c}\text { Faeces } \\
\text { \% } \text { of }{ }^{14} \mathrm{C} \text { fed }\end{array}$ & $\mathrm{kg}$ & $\begin{array}{c}\text { Urine } \\
{ }^{14} \mathrm{C} \text {-activity, } \\
\text { of }{ }^{14} \mathrm{C} \text { fed }\end{array}$ \\
\hline 8.1 & 5.9 & 0.0 & 4.6 & 92.8 \\
22.0 & 9.7 & 0.5 & 3.8 & 5.4 \\
32.2 & 7.7 & 0.6 & 3.8 & 0.3 \\
45.5 & 7.5 & 0.4 & 6.0 & 0.1 \\
56.2 & 12.7 & 0.0 & 4.6 & 0.1 \\
69.8 & 9.9 & 0.3 & 4.7 & 0.0 \\
80.3 & 7.0 & 0.3 & 5.6 & 0.0 \\
93.4 & 10.6 & 0.7 & 6.5 & 0.0 \\
104.1 & 7.0 & 0.1 & 5.4 & 0.0 \\
117.8 & 12.0 & 0.1 & 7.3 & 0.1 \\
\hline Total & & 3.0 & & 98.8 \\
\hline
\end{tabular}

In the faeces and urine of the 0 -cow totals of $2.5 \%$ and $23.5 \%$, respectively, of the ${ }^{14} \mathrm{C}$ fed were excreted (Table 2). The corresponding figures for the ULP-cow were $3.0 \%$ and $98.8 \%$ (Table 3 ).

\section{Discussion}

The feed of ruminants generally contains large amounts of benzoic acid precursors, for example aromatic amino acids, cyclohexane compounds, and they are also formed in rumen fermentation. The detoxication of these compounds in the organism usually takes place via benzoic acid, which is conjugated in the liver with glycine and removed, as hippuric acid, from the organism via the kidney and urine. The conjugation of feed benzoic acid with glycine is usually quantitative, and it has been observed with rabbits that the reaction 
rate is independent of the amount of benzoic acid fed (BRAY et al. 1951). According to studies performed with non-ruminants, the reaction rate may be governed by the amount of glycine available, the activity of the two enzymes required and the presence of inhibitory factors (IRJALA 1972).

The use of labelled benzoic acid in studies on ruminant metabolism has not apparently been reported previously in the literature. In the present study, $98.2 \%$ of the ${ }^{14} \mathrm{C}$-activity fed was recovered in the urine of the ULP-cow during the first day. It seems that $\left[{ }^{14} \mathrm{C}\right]$ benzoic acid was metabolised during this time almost quantitatively in the normal way. In contrast, with the 0 -cow the ${ }^{14} \mathrm{C}$-activity in the urine was considerably lower; during the first $24 \mathrm{~h}$ only $21.5 \%$ of the activity fed was excreted. During the following day a further $1.5 \%$ was recovered, after which the rate of excretion dropped to level of about $0.1 \%$ per day. The capacity of 0 -cow Oona to metabolise feed benzoic acid was less complete and slower than that of ULP-cow Euru. The high amounts of glycine found in the blood plasma of the 0 -cow exclude the possibility of a deficiency of glycine (VIRTANen et al. 1972). As the ${ }^{14} \mathrm{C}$ activity of the urine, faeces and milk fell (in two days) to a constant level of about $0.1 \%$, it can be deduced that the later metabolism of benzoic acid remained very slow.

The ${ }^{14} \mathrm{C}$-activity recovered in the faeces $(2.5 \%$ with the 0 -cow and $3.0 \%$ with the ULP-cow) results either from alimentary canal secretions, or from a slight utilisation of benzoic acid by the rumen microbes for the synthesis of structural cell components, which remain undigested.

In the amounts of ${ }^{14} \mathrm{C}$ excreted in the milk a slight difference $(0.5 \%$ and $0.8 \%$ ) was found between the 0 -cow and the ULP-cow. The total of the ${ }^{14} \mathrm{C}$ contents in the major components of the milk from both cows $(0.2 \%)$ was less than that in the whole milk (Table 1). Svensen (1974) has shown that cow's milk contains small amounts of hippuric acid. It is transferred from the blood plasma by passive diffusion in the mammary gland to the milk plasma (MILLER et al. 1967).

As to the biosynthesis of milk components, benzoic acid is used only for protein synthesis, and even then in very small amounts.

On the basis of the feeding experiments it can be stated that cows adapted to low-protein, urea-rich feed are able to metabolise benzoic acid normally, whereas the detoxication of this compound by cows adapted to protein-free, purified feed is slower and less complete. However, this may be an indication of the small amount of aromatic compounds in a metabolic system in which all the necessary aromatic compounds have to be synthesised solely from hexosebased carbon sources.

\section{REFERENCES}

Bray, H. G., Thorpe, W. V. \& White, K. 1951. Kinetic studies of the metabolism of foreign organic compounds. Biochem. J. 48: 88-96.

Ettala, T. \& Kreula, M. 1976. Urinary nitrogen compounds in dairy cows fed urea as the sole or partial source of nitrogen. J. Sciest. Agric. Soc. Finl. 48: 323-335.

IrJALA, K. 1972. Synthesis of p-aminohippuric, hippuric, and salicyuric acids in experimental animals and man. Ann. Acad. Sci. Fenn. A. V Med. 154: 40 pp. 
Miller, G. E., Banerjee, N. C. \& Stowe, C. M. Jr. 1967. Diffusion of certain weak organic acids and bases across the bovine mammary gland membrane after systemic admistration. J. Pharm. Exp. Ther. 157: 245-253.

MäKınen, S. 1972. Aspects of the nitrogen metabolism and nutritional status of urea-fed dairy cattle. Ann. Acad. Sci. Fenn. A. II Chem. 165:67 pp.

RauramaA, A. \& Kreula, M. 1975. Utilization of acetate in the biosynthesis of milk components by a cow on purified protein-free feed. Finn. Chem. Lett. 140-154.

Svensen, A. 1974. Hippursyre og benzoesyre i melk og forskjellige meieriprodukter. Meieriposten $35-36: 731-734$.

Virtanen, A. I. 1963. Production der Kuhmilch ohne Protein mit Harnstoff und Ammoniumsalzen als Stickstoffquelle und gereinigten Kohlenhydrate als Energiequelle. Biochem. Z. $338: 443-453$.

- -1966 . Milk production of cows on protein-free feed. Science 153: 1603-1614.

- - , Etrala, T. \& Mäkınen, S. 1972. Milk production of cows on purified protein-free feed with urea and ammonium salts as the only nitrogen source and on non-purified feed with rising amounts of true protein. Festskrift til Prof. Dr. Agr. h.c. Knut Breirem til hans 70-års dag. pp. 249-275.

Ms received March 15, 1978

\title{
SELOSTUS
}

\section{Bentsoehapon metaboliasta proteiinittomilla puhdistetuilla rehuilla ja vähän proteiinia sisältävillä rehuilla ruokituilla koelehmillä}

\author{
M. Kreula, A. Raurama ja M. Tegengren \\ Biokemiallinen Tutkimuslaitos, Kalevankatu 56 B, 00180 Helsinki 18
}

Proteiinittomalla, puhdasrehuruokinnalla olleen lehmän (0-lehmä) ja vähän proteiinia, runsaasti ureaa sisältävällä ruokinnalla olleen lehmän (ULP-lehmä) bentsoehappometaboliaa on seurattu käyttämällä $\left[{ }^{14} \mathrm{C}\right]$ :llä leimattua bentsoehappoa. 0- ja ULP-lehmälle on annettu kerta-annoksena suun kautta vastaavasti $212 \mu \mathrm{Ci}$ :tä ja $193 \mu \mathrm{Ci}$ :tä [rengas-14 $\mathrm{C}$ ] bentsoehappoa $0.01 \%$ bentsoehappoliuoksessa. Viiden vuorokauden ajan maito, sonta ja virtsa on kerätty kvantitatiivisesti. Maitonäytteistä on määritetty rasva-, proteiini- ja laktoosipitoisuudet, nämä aineosat on eristetty myös puhtaina. $23,5 \%$ ja $98,8 \%$ vastaavasti 0 - ja ULPlehmälle annetusta ${ }^{14} \mathrm{C}$-aktiivisuudesta on löydetty virtsasta ja 2,5\% ja 3,0 \% sonnasta. Kaikkiaan $0,5 \%$ ja $0,8 \%$ on löydetty kokomaidosta. Eristettyjen rasva-, proteiini- ja laktoosiaineosien ${ }^{14} \mathrm{C}$-aktiivisuuksien summa on ollut $0,2 \%$ molemmilla lehmillä vain proteinin leimaantuessa.

Näyttää siltä, että ULP-lehmä pystyy metaboloimaan bentsoehappoa normaaliin tapaan, mutta 0-lehmän bentsoehappo-detoksikaatio on normaalia hitaampaa ja epätäydellisempäå. 